\title{
Management of Phyllodes Tumors of the Breast: Our Clinical Experience
}

\section{Memenin Filloid Tümörlerinin Yönetimi ve Klinik Deneyimlerimiz}

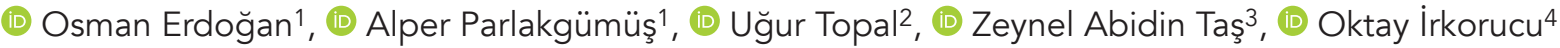 \\ ${ }^{1}$ Adana City Training and Research Hospital, Clinic of Surgical Oncology, Adana, Turkey \\ ${ }^{2}$ University of Health Sciences Turkey, Başakşehir Çam and Sakura City Hospital, Clinic of Surgical Oncology, İstanbul, Turkey \\ ${ }^{3}$ Adana City Training and Research Hospital, Clinic of Pathology, Adana, Turkey \\ ${ }^{4}$ Universty of Sharjah, College of Medicine, Department of Clinical Sciences, Sharjah, United Arab Emirates
}

\begin{abstract}
Objective: This study aimed to examine the demographic features, clinicopathological findings, follow-up results, and treatment methods of patients treated for phyllodes tumors of the breast in light of the literature.

Methods: All patients with benign, borderline, or malignant phyllodes tumors admitted to our hospital between 2013 and 2020 were retrospectively analyzed.

Results: The study included a total of 14 patients with phyllodes tumors of the breast on histopathological examinations, wherein 6 were benign (42.9\%), 3 were borderline (21.4\%), and 5 were malignant (35.7\%). The mean age was similar in the groups ( $p=0.654)$. Tumors were more frequently located in the right breast; however, no difference was found between the groups in terms of laterality $(p=0.514)$. The tumor diameter was significantly smaller in benign phyllodes (benign: $32 \mathrm{~mm}$, borderline: $72 \mathrm{~mm}$, and malignant: 80 mm, p=0.036). Benign phyllodes were more frequently breast imaging-reporting and data system (BI-RADS) 3 and malignant phyllodes were BI-RADS 5; however, the difference was not significant. A core needle biopsy was performed in eight patients as the most common biopsy method (57.1\%). The most common surgical procedure was segmental mastectomy (71.4\%). Re-excision was performed in three patients due to the surgical margin positivity or closeness. One patient received chemotherapy and radiotherapy (RT) and 4 patients only received RT. The mean follow-up time was $53.8 \pm 25.4$ months (13-96 months). Local recurrences occurred in two patients during the follow-up. Distant metastases or deaths were not observed.
\end{abstract}

Conclusion: Phyllodes tumors are rare, mixed-type breast tumors. Histopathological features and classification guide the management plan. Extensive analysis of phyllodes tumors is still lacking, and more studies are necessary to understand the behavior of this rare breast tumor.

Keywords: Breast, phyllodes tumor, fibroadenoma, surgery

\section{öz}

Amaç: Filloid meme tümörü tedavisi gören hastalarımızın demografik özelliklerini, klinikopatolojik bulgularını, takip sonuçlarını ve tedavi yöntemlerini literatür ışığında incelemeyi amaçladık.

Gereç ve Yöntem: Kurumumuza 2013-2020 yılları arasında başvuran benign, borderline veya malign filloid tümörlü tüm hastalar retrospektif olarak incelendi.

Bulgular: Histopatolojik olarak 6 benign $(\% 42,9), 3$ borderline $(\% 21,4)$ ve 5 malign filloid tümör $(\% 35,7)$ olmak üzere toplam 14 hasta dahil edilebildi. Ortalama yaş gruplarda benzerdi $(p=0,654)$. Sağ meme daha sık lokalize olmasına rağmen lokalizasyon açısından gruplar arasında farklılık yoktu ( $p=0,514)$. Benign grupta tümör çapı düşüktü (benign: 32 mm, borderline: 72 mm, malign: 80 mm, $p=0,036$ ). Benign grupta BIRADS 3 ve malign grupta BIRADS 5 ağırlık olmasına rağmen, istatistiksel olarak fark yoktu. En yaygın biyopsi yöntemi olarak 8 (\%57,1) hastaya tru-cut biyopsi yapıldı. En yaygın cerrahi prosedür segmental mastektomiydi $(\% 71,4)$. Üç hastaya cerrahi sınırın pozitifliği veya yakınlığı nedeniyle yeniden eksizyon yapıldı. Bir hasta kemoterapi ve radyoterapi aldı ve 4 hasta radyoterapi aldı. Ortalama takip süresi 53,8 $\pm 25,4$ aydı (13-96). Takip sırasında 2 hastada lokal nüks meydana geldi. Uzak metastaz veya ölüm yoktu.

Address for Correspondence: Osman Erdoğan, Adana City Training and Research Hospital, Clinic of Surgical Oncology, Adana, Turkey

Phone: +90 5077630121 E-mail: osman_erdogan85@hotmail.com ORCID ID: orcid.org/0000-0002-9941-2704 
Sonuç: Phyllodes tümörler nadir görülen, mikst tip meme tümörleridir. Yönetim planına histopatolojik özellikler ve sınıflandırma rehberlik eder. Filloid tümörlerin kapsamlı analizi hala eksiktir ve bu nadir meme tümörünün davranışını anlamak için daha fazla çalışmaya ihtiyaç vardır.

Anahtar Kelimeler: Meme, filloid tümör, fibroadenom, cerrahi

\section{INTRODUCTION}

Phyllodes tumors are rare fibroepithelial lesions consisting of $2 \%-3 \%$ of all fibroepithelial tumors and $0.3 \%-0.5 \%$ of all breast tumors in women, which are clinically confused with fibroadenomas. A large, rapidly growing mass and detection of stromal hyperplasia and atypia on histopathological examination should suggest a phyllodes tumor. Due to their rarity, literature data are limited. The World Health Organization (WHO) classifies phyllodes tumors into three histological subtypes based on the number of histopathological parameters, i.e., benign, borderline, and malignant $(1,2)$.

Surgery forms the basis for phyllodes tumor treatment. Preoperative diagnosis is very important for correct surgical planning. Difficulties in diagnosis during the preoperative period cause mistakes in treatment planning. Traditionally, considering the risk of local recurrences, wide local excision with a tumor-free border of $1 \mathrm{~cm}$ or more is recommended regardless of the subtype. Lumpectomy or partial mastectomy is the preferred surgical treatment. Total mastectomy is only necessary when negative margins are not achieved with breast-conserving surgery. Considering that a phyllodes tumor rarely metastasizes to the axillary lymph nodes (10\%-15\%), surgical axillary staging is not required unless lymph nodes are palpated upon clinical examination $(3,4)$.

The borderline and malignant phyllodes tumor metastasis rate is approximately $25 \%-31 \%$, whereas the overall rate of all phyllodes tumor metastases is $4 \%$. In addition, $\mathrm{WHO}$ reported a local recurrence rate of $21 \%(17 \%, 25 \%$, and $27 \%$ for benign, borderline, and malignant phyllodes tumors, respectively) $(5,6)$. Surgical margin positivity was reported in the literature to be associated with tumor size, surgical treatment technique, and tumor-related histopathological features $(7,8)$.

Evidence from randomized controlled trials and available data in the literature is insufficient to determine the treatment approach for phyllodes tumors. Therefore, this study aimed to examine the demographic characteristics, clinicopathological findings, follow-up results, and treatment methods of patients treated for phyllodes tumors of the breast in light of the literature.

\section{METHODS}

After obtaining approval from the Ethical Committee of Adana City Training and Research Hospital on January 27, 2021 (approval number: 75/1269), data about patients with phyllodes tumors treated in our hospital between 2013 and 2020 were retrospectively analyzed. Data were gathered from the results of pathological examinations and soft and hard copies of the patient files. Missing information about the patients was obtained by phoning them. Patients were divided into three groups based on the histopathological examination results, benign, borderline, and malignant. Age, complaints on admission, tumor location, surgery, breast imaging-reporting and data system (BIRADS) score, pathological features, tumor size, postoperative recurrence, and metastasis were compared in these groups.

Ultrasonography (USG) and mammography (MMG) were used as primary imaging methods. Histopathological diagnosis was made through core needle, excisional, and incisional biopsy methods. Pathologically, phyllodes tumors were classified into benign, borderline, and malignant based on the criteria reported by the WHO (1).

In the present study, the presence of 0-4 mitoses in each field examined under $10 \mathrm{X}$ magnification, minimal stromal cellularity, and minimal and moderate stromal development was considered benign phyllodes tumor. The presence of 5-9 mitoses in each field examined under $10 \mathrm{X}$ magnification, moderate stromal cellularity, and atypia was regarded as a borderline phyllodes tumor. The presence of $>10$ mitoses in each field examined under $10 \mathrm{X}$ magnification, moderate or severe stromal cellularity, atypia, and overgrowth and infiltrates to the surrounding tissues indicated a malignant phyllodes tumor.

A wide local excision, breast-conserving surgery, mastectomy, or mastectomy, and axillary lymph node dissection [modified radical mastectomy (MRM)], which are the treatment methods to be performed, were selected to leave a clean surgical margin of at least $1 \mathrm{~cm}$ according to the location, size, and histopathological diagnosis of the tumor. The close surgical margin was considered a clean surgical margin of $<1 \mathrm{~cm}$ in all types.

\section{Statistical Analysis}

Statistical analysis was made using the Statistical Package Program for Social Sciences 24.0 (IBM Corporation, 
Armonk, NY, USA). Descriptive data were expressed in mean and standard deviation for quantitative variables and in frequency and percentage for qualitative variables. Data with a normal distribution were evaluated using the Student's t-test, whereas data without a normal distribution were evaluated using the Fisher's Exact or Pearson's chisquare test. A p-value of $<0.05$ was considered statistically significant.

\section{RESULTS}

A total of 14 patients were included in the study, wherein 6,3 , and 5 were assigned into the benign, borderline, and malignant groups, respectively. The mean age was similar in the groups $(p=0.654)$. Tumors were more frequently located in the right breast accounting for $78.6 \%$ of the cases; however, no significant difference was found in terms of laterality $(p=0.514)$. All patients presented with a palpable mass. The tumor diameter was significantly smaller in the benign group (benign group: $32 \mathrm{~mm}$, borderline group: $72 \mathrm{~mm}$, and malignant group: $80 \mathrm{~mm}, \mathrm{p}=0.036$ ). A higher rate of tumors in the benign and malignant groups was $\mathrm{BI}$ RADS 3 and BI-RADS 5; however, the difference was not statistically significant $(p=0.141)$.

Regarding the biopsy method, a core-needle biopsy was performed in eight patients (57.1\%), excisional biopsy in five patients (35.7\%), and incisional biopsy in one patient (7.1\%). No significant difference was found in the biopsy methods between groups $(p=0.178)$

Breast-conserving surgery was performed with a wide local excision in all six patients with benign phyllodes tumors. Two patients had close resection margins. These patients did not undergo re-excision surgery. No local recurrence was observed in the benign phyllodes group during the follow-up.

Three patients had borderline phyllodes tumors (5\%). One of these patients immediately underwent a simple mastectomy after the core needle biopsy due to advanced tumor size. Another patient had a positive resection margin after breastconserving surgery and underwent a mastectomy. She also had a submuscular prosthesis for cosmetic reasons. The last patient underwent re-excision due to the proximity of the surgical margin after wide local excision.

Five patients had malignant phyllodes tumors (35.7\%). Three of them underwent breast-conserving treatment, one underwent a mastectomy, and one underwent MRM. One of the patients who underwent breast-conserving surgery was found with malignant phyllodes tumor and low nuclear grade intraductal carcinoma foci within the tumor on the permanent pathology sections after wide local excision. No tumor was left in the surgical resection margins. Sentinel lymph node biopsy was not performed. The tumor diameter was $12 \mathrm{~cm}$ in the patient who underwent a mastectomy, which was performed immediately after incisional biopsy. The patient who underwent MRM had a malignant phyllodes tumor accompanied by invasive ductal carcinoma detected on segmental resection. Positivity was found in some parts of the surgical margins and axillary lymph node involvement on USG. Therefore, MRM was subsequently performed.

None of the patients with benign and borderline phyllodes tumors received chemotherapy or radiotherapy (RT). All patients with malignant phyllodes tumors received RT, and the patient with invasive cancer and malignant phyllodes tumors received chemotherapy and hormone therapy.

The mean follow-up period was 53.8 \pm 25.4 months (1396 months). Local recurrences occurred in two patients during the follow-up. One of them had a malignant phyllodes tumor and underwent re-excision surgery due to tumor-positive resection margins. However, she had a malignant relapse in the tenth month, thus a mastectomy was performed. The other patient developed a borderline phyllodes tumor recurrence locally 14 months after the primary breast-conserving surgery despite the excision surgery for borderline phyllodes tumor. This patient was also treated with mastectomy. No distant metastases or deaths were observed Table 1.

\section{DISCUSSION}

The uncertain and heterogeneous biological behavior of phyllodes tumors makes the diagnosis and management more difficult. Therefore, clinicians relied heavily on reports from retrospective studies of this tumor's behavior to improve early diagnosis and use correct treatment strategies. In the present study, data of 14 female patients diagnosed with phyllodes tumor in our tertiary hospital over an 8-year-period were reviewed, and obtained results will contribute to the reported data.

Phyllodes tumors are more common in women aged 3555 years and the frequency of malignant phyllodes tumors increases in the older age group $(9,10)$. The mean age in our series was 34.5 years; however, no relationship was found between the histological subtype and age. In a large case series in the literature, benign, borderline, and malignant tumors were found in $72.7 \%, 18.4 \%$, and $8.9 \%$ of 605 patients, respectively. In another study, benign, borderline, and malignant phyllodes tumors were reported in $60 \%$, $20 \%$, and $20 \%$ of patients, respectively $(11,12)$. In our series, benign, borderline, and malignant phyllodes tumors were 
Table 1. The distribution of clinicopathological features by histopathological subtypes

\begin{tabular}{|c|c|c|c|c|c|}
\hline & Total & Benign phyllodes & Borderline phyllodes & Malignant phyllodes & $p$ \\
\hline Number of patients & 14 & $6(42.9 \%)$ & $3(21.4 \%)$ & $5(35.7 \%)$ & - \\
\hline $\begin{array}{l}\text { Age (years) } \pm S D \\
(\min -\max )\end{array}$ & $\begin{array}{l}39.6 \pm 15 \\
(22-70)\end{array}$ & $\begin{array}{l}35.1 \pm 10.6 \\
(25-55)\end{array}$ & $\begin{array}{l}41.6 \pm 25.1 \\
(22-70)\end{array}$ & $\begin{array}{l}43.8 \pm 14.9 \\
(26-63)\end{array}$ & 0.654 \\
\hline \multicolumn{6}{|l|}{ Laterality } \\
\hline Right & $11(78.6 \%)$ & $4(28.6 \%)$ & $3(21.4 \%)$ & $44(28.6 \%)$ & \multirow{2}{*}{0.514} \\
\hline Left & $3(21.4 \%)$ & $2(14.3 \%)$ & 0 & $11(7.1 \%)$ & \\
\hline Size $(m m) \pm S D(\min -m a x)$ & $54.9 \pm 31(22-120)$ & $31.5 \pm 7(22-40)$ & $67.3 \pm 34(32-100)$ & $75 \pm 33.1(40-120)$ & 0.036 \\
\hline \multicolumn{6}{|l|}{ BI-RADS } \\
\hline III & - & $4(28.6 \%)$ & $1(7.1 \%)$ & 0 & \multirow{3}{*}{0.141} \\
\hline IV & - & $2(14.3 \%)$ & $1(7.1 \%)$ & $2(14.3 \%)$ & \\
\hline V & - & 0 & $1(7.1 \%)$ & $3(21.4 \%)$ & \\
\hline \multicolumn{6}{|l|}{ Biopsy method } \\
\hline Core needle & 8 (57.1\%) & 2 (14.3\%) & 2 (14.3\%) & $4(28.6 \%)$ & \multirow{3}{*}{0.178} \\
\hline Excisional & 5 (35.7\%) & $4(28.6 \%)$ & 1 (7.1\%) & 0 & \\
\hline Incisional & $1(7.1 \%)$ & 0 & 0 & $1(7.1 \%)$ & \\
\hline
\end{tabular}

Surgical method

\begin{tabular}{lllll}
\hline Breast conserving & $10(71.5 \%)$ & $6(42.9 \%)$ & $1(7.1 \%)$ & $3(21.4 \%)$ \\
\hline Mastectomy & $3(21.4 \%)$ & 0 & $2(14.3 \%)$ & $1(7.1 \%)$ \\
\hline MRM & $1(7.1 \%)$ & 0 & 0 & $1(7.1 \%)$ \\
\hline $\begin{array}{l}\text { Re-excision for positive or close } \\
\text { margin }\end{array}$ & $3(21.4 \%)$ & 0 & $1(7.1 \%)$ & $2(14.3 \%)$ \\
\hline Margin status & $12(85.7 \%)$ & $4(28.6 \%)$ & $3(21.4 \%)$ & $5(35.7 \%)$ \\
\hline Negative & $2(14.3 \%)$ & $2(14.3 \%)$ & 0 & 0 \\
\hline Close & 0 & 0 & 0 & 0 \\
\hline Positive & $2(14.3 \%)$ & 0 & $1(7.1 \%)$ & $1(7.1 \%)$ \\
\hline Local recurrence & & & 0.233 \\
\hline
\end{tabular}

BI-RAD: Breast imaging reporting and data system, MRM: Modified radical mastectomy, SD: Standard deviation, min-max: minimum-maximum

detected in $42.9 \%, 21.4 \%$, and $35.9 \%$ of cases, respectively. The rate of malignant phyllodes tumors in this series was higher than that reported in the literature.

Phyllodes tumors widely vary in size. This variation in tumor size is due to the late diagnosis of the tumor caused by diagnostic difficulties and the benign or malignant nature of the tumor. In general, tumor size varies with benign and borderline or malignant phyllodes tumors (9). In a study by Wang et al. (9), the mean primary tumor diameter of the histological subtypes benign, borderline, and malignant phyllodes tumors was found to be $3.7 \mathrm{~cm}, 4.8 \mathrm{~cm}$, and 7.5 $\mathrm{cm}(\mathrm{p}<0.000)$, respectively. Based on multivariate analysis, larger masses were reported to be more likely malignant ( $p=0.052$, odds ratio: 1.127) (9). In our series, the mean tumor diameter was $5.4 \mathrm{~cm}$, and borderline and malignant tumors had a larger tumor diameter.
Phyllodes tumor diagnosis is difficult in daily clinical practice. Failure to preoperatively diagnose malignant phyllodes tumors causes short-term recurrences and even distant metastases due to insufficient excision. Contrarily, radiological and histopathological examinations of phyllodes tumors often yield similar findings to the examinations of fibroadenomas, thus clinical suspicion is essential for diagnosis (13). MMG and USG used in the diagnosis of breast masses are not very reliable methods in making the differential diagnosis of phyllodes tumors from fibroadenomas (14). Fine needle aspiration biopsies are generally inadequate due to their high false-negative rates. Core needle biopsies play an important role in the diagnosis of phyllodes tumors; however, false-negative results at the rates of $25 \%-30 \%$ were reported $(15,16)$. In our series, the BIRADS 4-5 was more common in patients with the malignant subtype. 
The treatment of phyllodes tumors is surgical excision with sufficient margins. Recurrences and the need for reoperation increase after inadequate surgery (17). In a multivariate analysis performed with 172 patients, insufficient margins were found to play a role in the emergence of local recurrences and metastases (18). Different opinions were presented on the surgical method to be chosen in the literature. Sotheran et al. (19) recommended a wide local excision in phyllodes tumors, whereas Sotheran et al. (19) recommended mastectomy (20). Kapiris et al. (21) could not find a difference between wide local excision and mastectomy in the presence of negative margins. In the current study, segmental mastectomy was performed in patients for whom clean surgical margins are achieved, and mastectomy or subcutaneous mastectomy was performed in the patients in whom clean surgical margins were not achieved or poor cosmetic results were likely to appear after excision.

The benefit of adjuvant chemotherapy for phyllodes tumors is controversial. No prospective or randomized studies were reported about the effect of adjuvant chemotherapy on this type of tumor. Using adjuvant RT is also controversial in the literature. The National Comprehensive Cancer Network and other studies recommend the use of RT in cases of recurrent malignant phyllodes. Other studies recommend adjuvant RT to reduce the likelihood of local recurrences in patients with borderline and malignant phyllodes tumors treated with breast-conserving surgery. Contrarily, RT did not increase the overall survival (OS) and disease-free survival rates $(22,23)$. In our series, five patients received RT who had malignant phyllodes tumors. The patient receiving chemotherapy are those with invasive carcinoma.

In the series of the MD Anderson cancer center, 5-year OS rates in patients with benign and malignant phyllodes tumors were $91 \%$ and $82 \%$, respectively (24). According to data from the Surveillance, Epidemiology, and End Results Program of the National Cancer Institute, the 5-year OS rate was $91 \%$ for malignant cases (25). In another study, the 3 -year survival rate for benign/borderline tumors was $100 \%$, whereas $53.4 \%$ in patients with malignant phyllodes tumors (26). Acar et al. (14) reported that the 5-year OS rate was $89 \%$ for borderline and malignant cases. Kündeş et al. (27) found that the 5 -year survival was $93.8 \%$ and $70 \%$ in borderline and malignant tumors, respectively. In our series, none of the patients died during the 53-month follow-up.

Local recurrence rates in the follow-up of patients with phyllodes tumors were reported to range from $10 \%$ to $40 \%$ in different studies. Local recurrences are often detected in the breast tissue, but rarely, local-regional recurrences including the chest wall can be detected. Especially in borderline and malignant phyllodes tumors, the probability of local recurrence was reported to be $21 \%$ even if the surgical margins are negative $(28,29)$. Metastasis rates for phyllodes tumors vary between $13 \%$ and $40 \%$. The most common site of metastasis is in the lungs. The current approach to the treatment of metastatic lesions is surgical excision (28). In our series, during the 53-month follow-up period, local recurrences developed in two patients with borderline and malignant phyllodes tumors. Three patients underwent re-excision due to positive surgical margins and one of them had a local recurrence. In the present study, the total local recurrence rate was $14 \%$ and none of the patients developed distant organ metastasis.

\section{CONCLUSIONS}

Phyllodes tumors are rare breast tumors with variable biological behavior and heterogeneous radiological and clinical manifestations. Histopathological features and classification guide the management plan. Extensive analysis of phyllodes tumors is still lacking, and more studies are necessary to understand the behavior of this rare breast tumor.

\section{ETHICS}

Ethics Committee Approval: The study were approved by the Adana City Training and Research Hospital of Local Ethics Committee (protocol number: 27.01.2021/75/1269).

Informed Consent: Consent form was filled out by all participants.

\section{Authorship Contributions}

Surgical and Medical Practices: O.I., O.E., Concept: O.E., A.P., Design: O.E., O.I., Data Collection or Processing: Z.A.T., U.T., Analysis or Interpretation: U.T., O.E., Literature Search: U.T., O.E., O.I., Writing: O.E., U.T.

Conflict of Interest: No conflict of interest was declared by the authors.

Financial Disclosure: The authors declared that this study received no financial support.

\section{REFERENCES}

1. Lakhani SR, Ellis IO, Schnitt SJ, Tan PH, van de Vijver MJ. WHO classification of tumours of the breast. IARC: Lyon; 2019.

2. Yılmaz S, Aykota MR, Arman Karakaya Y, Özgen U, Erdem E. Phyllodes Tumors of the Breast: A Single-Center Experience. Eur J Breast Health 2020;17:36-41.

3. National Comprehensive Cancer Network. Breast cancer, Version 6.2020. https ://www.nccn.org/professionals/physician_gls/pdf/ breast.pdf. [Accessed 22 November 2020] 
4. Genco IS, Purohit V, Hackman K, Ferreira L, Tugertimur B Hajiyeva S. Benign and borderline phyllodes tumors of the breast: Clinicopathologic analysis of 205 cases with emphasis on the surgical margin status and local recurrence rate. Ann Diagn Pathol 2021;51:151708.

5. Lakhani SR, Ellis IO, Schnitt SJ, Tan PH, van de Vijver MJ. World Health Organization classification of tumors of the breast. In: World Health Organization classification of tumors; 2012.

6. Alkushi A, Arabi H, Al-Riyees L, Aldakheel AM, Al Zarah R, Alhussein $F$, et al. Phyllodes tumor of the breast clinical experience and outcomes: A retrospective cohort tertiary hospital experience. Ann Diagn Pathol 2021;51:151702.

7. Li J, Tsang JY, Chen C, Chan SK, Cheung SY, Wu C, et al. Predicting Outcome in Mammary Phyllodes Tumors: Relevance of Clinicopathological Features. Ann Surg Oncol 2019;26:2747-58.

8. Zhou ZR, Wang CC, Yang ZZ, Yu XL, Guo XM. Phyllodes tumors of the breast: diagnosis, treatment and prognostic factors related to recurrence. J Thorac Dis 2016:8:3361-8.

9. Wang $H$, Wang $X$, Wang CF. Comparison of clinical characteristics between benign borderline and malignant phyllodes tumors of the breast. Asian Pac J Cancer Prev 2014;15:10791-5.

10. Bernstein L, Deapen D, Ross RK. The descriptive epidemiology of malignant cystosarcoma phyllodes tumors of the breast. Cancer 1993;71:3020-4

11. Suzuki-Uematsu $S$, Shiraishi $K$, Ito $T$, Adachi $N$, Inage $Y$, Taeda $Y$, et al. Malignant phyllodes tumor composed almost exclusively of a fibrosarcomatous component: a case report and review of malignant phyllodes tumors with metastases. Breast Cancer 2010;17:218-24.

12. Ogunbiyi S, Perry A, Jakate K, Simpson J, George R. Phyllodes tumour of the breast and margins: How much is enough. Can $\mathrm{J}$ Surg 2019;62:E19-E21.

13. Atalay C, Kınas V, Celebioglu S. Analysis of patients with phyllodes tumor of the breast. Ulus Cerrahi Derg 2014;30:129-32.

14. Acar T, Tarcan E, Hacıyanlı M, Kamer E, Peşkersoy M, Yiğit S, et al. How to approach phyllodes tumors of the breast? Ulus Cerrahi Derg 2015;31:197-201.

15. Jacklin RK, Ridgway PF, Ziprin P, Healy V, Hadjiminas D, Darzi A. Optimising preoperative diagnosis in phyllodes tumour of the breast. J Clin Pathol 2006;59:454-9.

16. Dillon MF, Quinn CM, McDermott EW, O'Doherty A, O'Higgins $\mathrm{N}$, Hill AD. Needle core biopsy in the diagnosis of phyllodes neoplasm. Surgery 2006;140:779-84.

17. Dalcı K, Gul MO, Sarıtas AG, Gümüş S, Sakman G, Ergin M. Clinical features and course of Phyllodes tumors of breast. Cukurova Med J 2020;45:1217-24.
18. Spitaleri G, Toesca A, Botteri E, Bottiglieri L, Rotmensz N, Boselli $\mathrm{S}$, et al. Breast phyllodes tumor: a review of literature and a single center retrospective series analysis. Crit Rev Oncol Hematol 2013;88:427-36.

19. Sotheran W, Domjan J, Jeffrey M, Wise MH, Perry PM. Phyllodes tumours of the breast--a retrospective study from 1982-2000 of 50 cases in Portsmouth. Ann R Coll Surg Engl 2005;87:339-44.

20. Ben Hassouna J, Damak T, Gamoudi A, Chargui R, Khomsi F, Mahjoub S, et al. Phyllodes tumors of the breast: a case series of 106 patients. Am J Surg 2006;192:141-7.

21. Kapiris I, Nasiri N, A'Hern R, Healy V, Gui GP. Outcome and predictive factors of local recurrence and distant metastases following primary surgical treatment of high-grade malignant phyllodes tumours of the breast. Eur J Surg Oncol 2001;27:723-30.

22. Carlson RW, Allred DC, Anderson BO, Burstein HJ, Edge SB, Farrar WB, et al. Metastatic breast cancer, version 1.2012: featured updates to the NCCN guidelines. J Natl Compr Canc Netw 2012;10:821-9.

23. Zeng S, Zhang X, Yang D, Wang X, Ren G. Effects of adjuvant radiotherapy on borderline and malignant phyllodes tumors: $A$ systematic review and meta-analysis. Mol Clin Oncol 2015;3:66371.

24. Chen AM, Meric-Bernstam F, Hunt KK, Thames HD, Oswald MJ, Outlaw ED, et al. Breast conservation after neoadjuvant chemotherapy: the MD Anderson cancer center experience. J Clin Oncol 2004;22:2303-12.

25. Macdonald OK, Lee CM, Tward JD, Chappel CD, Gaffney DK. Malignant phyllodes tumor of the female breast: association of primary therapy with cause-specific survival from the Surveillance, Epidemiology, and End Results (SEER) program. Cancer 2006;107:2127-33.

26. Chaney AW, Pollack A, McNeese MD, Zagars GK. Adjuvant radiotherapy for phyllodes tumor of breast. Radiat Oncol Investig 1998;6:264-7.

27. Kündeş MF, Çetin K, Kaya S, Küçük HF . Is the Surgical Approach Very Important to Treatment for Phyllodes Tumors?. South. Clin. Ist. Euras 2019;30:130-4.

28. Mishra SP, Tiwary SK, Mishra M, Khanna AK. Phyllodes tumor of breast: a review article. ISRN Surg 2013;2013:361469.

29. Barth RJ Jr, Wells WA, Mitchell SE, Cole BF. A prospective, multiinstitutional study of adjuvant radiotherapy after resection of malignant phyllodes tumors. Ann Surg Oncol 2009;16:2288-94. 